\title{
Some Metabolic Aspects of the Obese-Hyperglycemic Syndrome in Mice*
}

\author{
Bo Helliman
}

Department of Histology, University of Umeå, Umeå 6, Sweden

Summary. Some aspects of the metabolism of obesehyperglycemic mice are presented in the light of recent observations on the Swedish colony of these animals. A screening procedure has been elaborated, which allows early detection of those growing mice that will later develop the obese-hyperglycemic syndrome. The observation that intraperitoneal glucose injections induce a higher frequency of glucosuria in those suckling mice which are homozygous for the obese-hyperglycemic gene furthermore suggests that the impairment of the glucose metabolism represents a primary lesion in these animals. The obese-hyperglycemic syndrome is associated with a reduced endocrine activity of the testis. Quantitative microscopic analyses of the testis, both from obese-hyperglycemic mice kept on a restricted food intake and from mice in which hyperphagia and obesity had been induced by injections of gold thioglucose, revealed that other factors than overeating and/or obesity are responsible for the depression of the testis function. An increased activity of $\beta$-glucuronidase has been reported in serum and arteries from inviduals with diabetes or severe arteriosclerosis. However, among the various tissues analysed in the obese-hyperglycemic mice only the adrenals displayed a significantly higher $\beta$-glucuronidase activity than the lean litter mates. Studies of the enzymatic dehydrogenation of isocitrate revealed considerably higher ratios between the $\mathrm{NADP}^{+}$- and $\mathrm{NAD}^{+}$-specific enzyme activities in the skeletal muscle and liver from the obese-hyperglycemic mice. The observation that the liver dehydrogenation of isocitrate was more dependent on $\mathrm{NADP}^{+}$in the latter animals must not necessarily be attributed to the presence of a hyperlipogenesis, since similar ratios were recorded for the $\mathrm{NADP}^{+}$- and $\mathrm{NAD}^{+}$-linked isocitric dehydrogenase activities when the adipose tissue from the obese-hyperglycemic mice was compared with that from the lean sibling controls.

Quelques aspects du métabolisme du syndrome obèsehyperglycémique chez la souris.

Résumé. Nous avons passé en revue quelques aspects du métabolisme des souris obèses-hyperglycémiques observés dans la colonie suédoise de ces animaux. Nous avons développé une méthode de dépistage qui permet de reconnaître très tôt les animaux qui, plus tard, deviendront obèses et hyperglycémiques. L'injection intrapéritonéale de glucose mène plus fréquemment à une glucosurie chez les souris homozygotes (obob) même avant le sevrage, suggérant done que l'anomalie du métabolisme du glucose est une lésion primaire chez ces animaux. Le syndrome est en outre associé à une activité endocrme réduite du testicule. Une comparaison quantitative des structures testiculaires d'animaux obèses-hyperglycémiques soumis à un régime strict, et d'animaux obèses à la suite d'hyperphagie provoquée par l'injection d'aurothioglucose, permet d'affirmer que cette diminution de la fonction endo-

* Supported by the Swedish National Research Coun. cil $(12 \times-562-03)$ and the United States Public Health Service $(A M-05759-05)$. crine testiculaire est le résultat de facteurs autres que I'hyperphagie ou l'obésité. Une augmentation de la $\beta$ glucuronidase sérique et artérielle ayant été décrite chez des malades atteints de diabète ou d'artériosclérose sévères, cette activité enzymatique a été mesurée chez les souris obèses-hyperglycémiques. Une activité enzymatique accrue n'a été observée que pour les surrénales. La déshydrogénation de l'isocitrate procède plus activement par la voie requérant le cofacteur $\mathrm{NADP}^{+}$dans les tissus musculaires et hépatiques de souris obèses-hyperglycémiques, que ce n'est le cas pour les tissus de souris nonobèses. Pourtant, cette utilisation préférentielle de l'enzyme $\mathrm{NADP}^{+}$-dépendant n'est pas nécessairement liée à la lipogénèse accrue observée chez ces animaux, puisque cette même préférence ne se retrouve pas lorsqu'on compare le tissu adipeux d'animaux obèses et non-obèses de mêmes nichées.

Stoffwechseluntersuchungen beim Syndrom von Fettsucht und Hyperglykämie der Maus.

Zusammenfassung. Auf Grund von kürzlich durchgeführten Untersuchungen an der schwedischen Kolonie von fettsüchtig-hyperglykämischen Mäusen werden hier einige Gesichtspunkte über den Stoffwechsel dieser Tiere dargestellt. Eine neue Arbeitsweise hat es uns ermöglicht schon früh Mäuse, die später zu Fettsucht und Hyperglykämie neigen, zu entdecken. Intraperitoneale Glucoseinjektionen führten häufiger zur Glucosurie in denjenigen noch nicht entwöhnten Tieren, die für das fettsüchtighyperglykämische Gen homozygot sind. Diese Tatsache weist auch darauf hin, daß die Störung des Glucosestoffwechsels wahrscheinlich eine primäre Anomalie darstellt. Das fettsüchtig-hyperglykämische Syndrom geht parallel mit einer verminderten endokrinen Aktivität der Hoden. Quantitative mikroskopische Untersuchung der Hoden von sowohl fettsüchtig-hyperglykämischen Mäusen bei Beschränkung der Nahrungsaufnahme, als auch von Mäusen mit Goldthioglucose-bedingter Hyperphagie und Fettsucht deuten darauf, daß andere Faktoren als Überfressen oder Fettsucht für das Abnehmen der Hoden. funktion verantwortlich sind. Im Serum oder in den Arterien von Patienten mit Diabetes oder Arteriosklerose ist eine Vermehrung der $\beta$-Glucuronidase-Aktivität nachgewiesen worden. Bei fettsüchtig-hyperglykämischen Mäusen war aber nur in den Nebennieren eine höhere $\beta$-Glucuronidase-Aktivität als bei nicht-fettsüchtigen Tieren nachzuweisen. Untersuchung der enzymatischen Dehydrogenierung von Isocitrat zeigte, daß Isocitrat im Skelettmuskel und in der Leber dieser fettsüchtig hyperglykämischen Mäuse vorwiegend über das NADP+-abhängige Enzym dehydrogeniert wird. Diese Beobachtung ist nicht unbedingt mit der Hyperlipogenese verbunden, da das Fettgewebe von fettsüchtig-hyperglykämischen Mäusen im Vergleich zu dem der mageren nicht dieselbe Bevorzugung des NADP+- abhängigen Enzyms aufweist.

Key-words: Spontaneous Diabetes, Obese mice, Genotype : obob, Obese-hyperglycemic syndrome, Screening, for diabetes, Testis, Obesity, $\beta$-glucuronidase, Isocitrate metabolism, Muscle, Liver, Adipose tissue. 
During recent years various strains of mice that display a spontaneous development of obesity and hyperglycemia have been described. When simply referring to obese-hyperglycemic mice it seems, however, to be generally accepted that this description denotes those American mice that are homozygous for a single recessive gene and which were originally described by IrgaLus et al. (1950) as a new mutant from the R.B. Jackson Memorial Laboratory, Bar Harbor, Maine. The potential value of these animals (Fig. 1) for the study of various aspects of diabetes

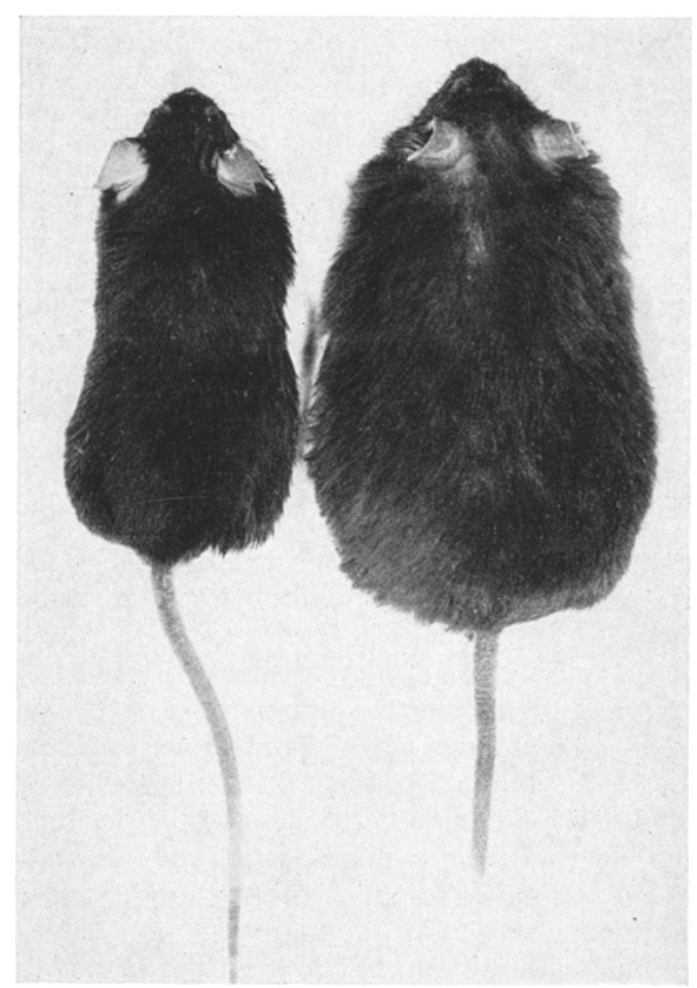

Fig. 1. The appearance of an obese-hyperglycemic mouse (right), as compared with one of its lean litter mates (left)

induced us to establish our own breed of them in 1959. The Swedish colony of obese-hyperglycemic mice has rapidly expanded, particularly after the introduction of a new technique for dissecting metabolically intact pancreatic islets (HELLERströM, 1964), which was found to be especially useful when applied to the considerably enlarged islets of the obese-hyperglycemic mice (Hentman et al., 1964).

Although the genetically obese mice from Bar Harbor have been the object of considerable interest from several laboratories over the years, the primary metabolic lesion still remains obscure. The present communication will describe some of the metabolic aspects of the obese-hyperglycemic syndrome, which have appeared in our laboratory after a more comprehensive survey was made at the New York Academy of Sciences (Hellivar, 1965).

\section{Glucose tolerance during the development of the obese-hyperglycemic syndrome}

The obese-hyperglycemic mice are indistinguishable in external appearance from their lean litter-mates during the first 4-6 postnatal weeks. The subsequent period is characterized by a rapid expansion of the subcutaneous depot fat giving body weights at least double those of the controls (TäLJEDAL and HELLMLAN, 1963; HELLMAN, 1965). On the other hand, the hyperglycemia is known to develop as late as the 12th to the 18th weeks of life. The precise time of onset of the hyperglycemia has been regarded as being conditioned by the presence or absence of genes other than "obese" in the genetic composition of the obese-hyperglycemic mice (MAYER and SILIDES, 1953).

For a proper understanding of the metabolic abnormalities of the obese-hyperglycemic mouse it is important to know whether the impaired glucose metabolism is secondary to the manifest obesity or whether it is a preceding phenomenon. This problem has been considered by performing systematic glucose tolerance tests on suckling mice of different ages. The results have been evaluated simply with respect to the presence or absence of glucosuria after intraperitoneal glucose injections (DaNIELsson et al., 1966). The experiments were performed between 10 and 11 a. $\mathrm{m}$. in a room with automatically controlled daylight 12 hours from $8 \mathrm{a} . \mathrm{m}$. After the animals had been taken from their mothers and weighed, they were injected intraperitoneally with a volume of $10 \%$ glucose compatible with a frequency of about $50 \%$ positive urinary glucose tests in each age group. One hour later the presence of glucosuria was checked with glucose oxidase strips and the whole procedure repeated after 24 hours. After some practice it was easy to empty the urinary bladder both at the beginning of the experiment and one hour after the injection by a gentle pressure over the lower part of the abdomen. By inspecting and weighing all the mice one month later, they could easily be classified as being either homozygous (AO-mice) or non-homozygous (AN-mice) for the obese-hyperglycemic syndrome.

The frequency of repeated positive urinary glucose tests in $\mathbf{2 5 6}$ suckling mice, representing three different age groups, is shown in Fig. 2. It was evident that with increasing age the doses of glucose had to be gradually increased in relation to the body weight to establish glucosuria. At an age of 18 days no significant differences were noted between the $\mathrm{AN}$-mice and the AO-mice $(P<0.01)$, despite their normal body weights. When 29 days old, repeated positive tests for glucosuria were obtained in as many as $\mathbf{9 0 \%}$ of the AO-mice but in none of the AN-mice after intraperitoneal injections of $300 \mathrm{mg}$ of glucose per $100 \mathrm{~g}$ body weight. Neither for the AN-mice nor for the AO-mice could any relationship be demonstrated between the body weight of the individual animal and the presence of urinary glucose. 
The inherent simplicity of evaluating the results only with respect to the presence or absence of glucose makes the present procedure particularly useful in large-scale screening for early detection of growing mice which are homozygous for the obese-hyperglycemia syndrome. The observation that the intraperitoneal glucose injections induce a higher frequency of positive urinary glucose tests even in the pre-obese state furthermore suggests that impairment of the glucose metabolism represents a primary lesion in the obese-hyperglycemic syndrome. The possibility that differences in either the rate of glucose absorption from the peritoneal cavity or the renal threshold for glucose may have contributed to the higher frequency of positive urinary glucose tests in the AO-mice should,

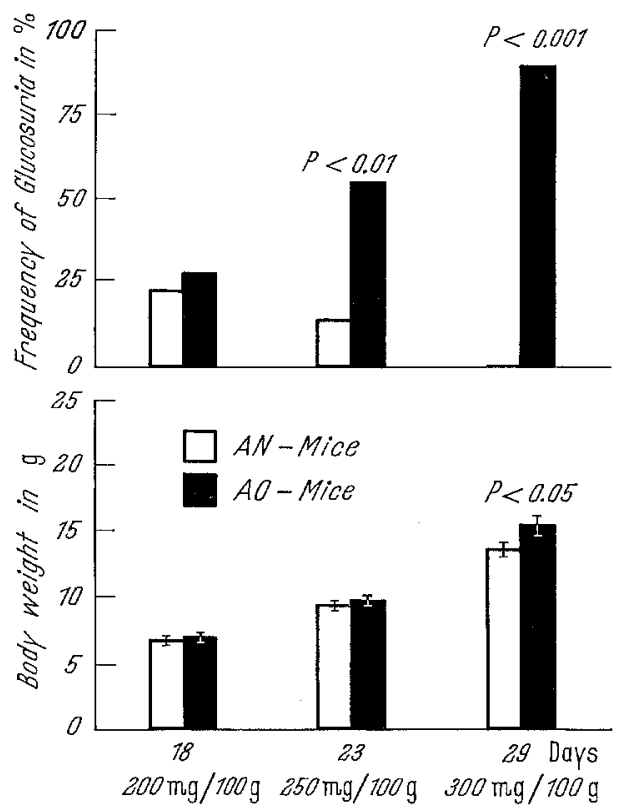

Fig. 2. The results of intraperitoneal glucose tolerance tests in growing mice studied with regard to whether they develop an obese-hyperglycemic syndrome (AO-mice) or not (AN-mice). The percentage of animals in each group displaying repeated positive tests for glucosuria at the 18th, $23 \mathrm{rd}$ and 29 th day of postnatal life is shown in the upper part of the figure and the corresponding body weights \pm S.E.M. (standard error of the means) in the lower part. While the amounts of glucose injected intraperitoneally corresponded to $200 \mathrm{mg}$ per $100 \mathrm{~g}$ body weight in the 18-day-old animals, the doses for the 23- and 29-day-old mice were $250 \mathrm{mg}$ and $300 \mathrm{mg}$ per $100 \mathrm{~g}$ body weight, respectively

however, be considered. On account of the technical problems associated with the performance of conventional intravenous glucose tolerance tests in a great number of suckling mice, there are so far only complementary data for the blood glucose level after intraperitoneal glucose injections. The latter studies (Westman, 1966) lend no support to the view that the renal threshold for glucose differs between the young $\mathrm{AN}$-mice or AO-mice but rather suggests that the blood glucose level provides a more sensitive index for early identification of the AO-mice than the presence or absence of glucosuria.
Previous observations of a considerable multiplication of the pancreatic $\beta$ cells in the obese-hyperglycemic mice (GEPTs et al., 1960; Hellman, 1965) with a resulting increase of the circulating insulin-like activity may well explain why no hyperglycemia will be manifest until 2 months after the first signs of a diminished glucose tolerance. Furthermore, since insulin increases fat synthesis by adipose tissue, it is reasonable to assume that the accumulation of fat in the obese-hyperglycemic syndrome is due, at least in part, to the response of the fat cells to increased local concentrations of this hormone. It has been suggested that a similar mechanism operates in the development of obesity associated with mice bearing ACTH-secreting tumours (HAUSBERGER and RAMSAY, 1959).

\section{Caloric intake and the endocrine activity of the testis}

In view of the reduced fertility of the obese-hyperglycemic mice, these animals are generally produced by breeding the heterozygous animals. After having shown that hormonal therapy could result in conception, implantation and maintenance of pregnancy in the homozygous females, SmIthrerg and RunNer (1957) concluded that the sterility associated with the obese-hyperglycemic syndrome was due to insufficient secretion of pituitary-gonadotrophins. A reduction of the pituitary-gonadotrophin function would also affect the endocrine activity of the testis, and we have been able to demonstrate definite microscopical signs of a reduced endocrine activity of this organ (HELLMaN et al., 1963). While all stages in the spermatogenesis were clearly evident without obvious degeneration of the spermatogenic epithelium, the Leydig cells appeared atrophic and their total volume was reduced by more than $50 \%$.

It has been stated that laboratory animals made obese by overfeeding or underactivity exhibit some degree of testicular atrophy (INGLE, 1950). The observation that some male obese-hyperglycemic mice became fertile when kept on a restricted diet and not allowed to exceed a weight of $25-30 \mathrm{~g}$ (LANE and DrCKIE, 1954) suggests that excessive food intake and overweight in itself may contribute to the reduction of the endocrine testis function also in these animals. The possibility that excessive caloric intake may induce testicular atrophy is of general interest and has led to quantitative microscopical studies of the testis from mice of different ages and nutritional status. Only part of this program has been completed up to now (Lidell and Hellmax, 1966), but the available data suggest that the deficient gonadotrophin secretion in the obese-hyperglycemic mice is a result of their diabetic state rather than altered caloric intake and/or overweight.

In the first type of experiments, the endocrine function of the testis was evaluated after elimination 
of established overweight by allowing 4-month-old obese-hyperglycemic mice only two feeding periods a day of a calorically defined diet (carbohydrate $38 \%$, fat $24.5 \%$ and protein $37.5 \%$ ). This resulted in a slow weight reduction until the body weights after 2 months were similar to those of their lean littermates. The absolute volumes of the different testicular

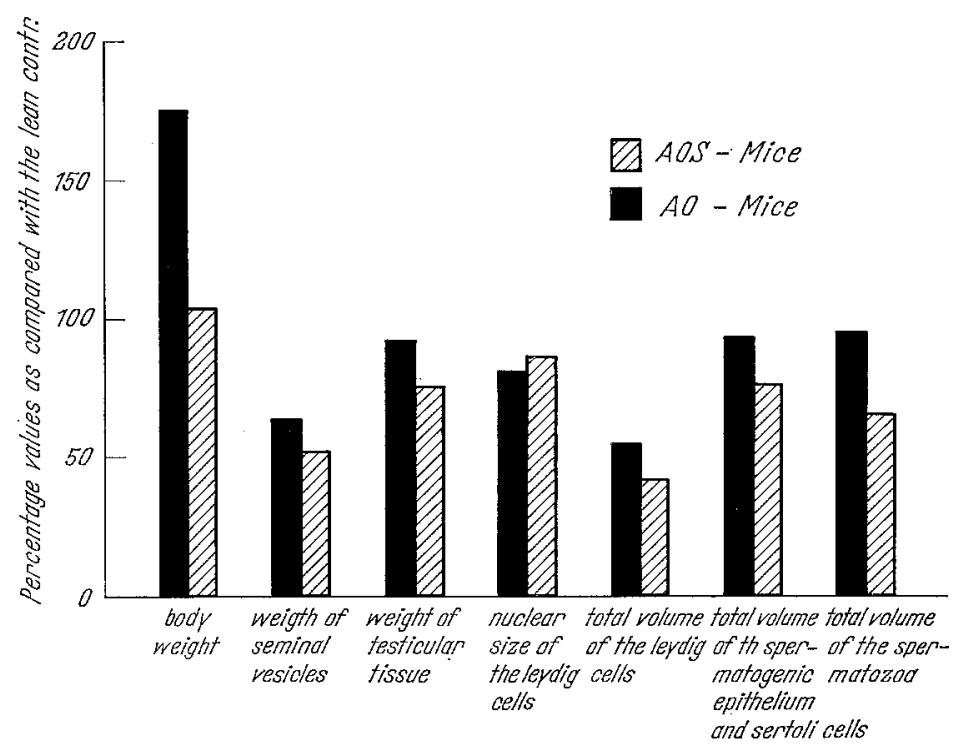

Fig. 3. The body weights (g), the weights of the testicular tissue and seminal vesicles (mg), the nuclear size of the Leydig cells (arbitrary units representing the projection area) and the total volumes of different testicular components $\left(\mathrm{mm}^{3}\right)$ in obese-hyperglycemic mice allowed free access to food (AO-mice) or kept on a restricted food intake resulting in a normalisation of the body weight (AOS-mice). The values have been expressed as percentages of the corresponding parameters for lean sibling controls allowed free access to food

components were calculated from the percentage figures obtained by performing microscopical point sampling on paraffin sections and from the weights of the gonads. In addition, the nuclear size of the Leydig cells was measured with the aid of an ocular screw micrometer. In Fig. 3 data have been presented not only for the obese-hyperglycemic mice when kept on the above-mentioned restricted diet (AOS-mice) but also when allowed free access to the same diet (AO-mice). In both cases the results have been expressed as percentages of the appropriate controls as represented by the lean litter-mates, which were allowed free access to the food. The figures presented in Fig. 3 corroborate our previous observations of a considerably reduced endocrine activity in the obesehyperglycemic syndrome (Heslmar et al., 1963). Both the nuclear size of the Leydig cells and the total volume of these cells were much smaller in the AOmice than in the lean controls. Furthermore, the hypoplasia of the seminal vesicles is worthy of note, since it is known that the size of these glands represents a very sensitive index for assays of male sex hormones (DoRFMann and SHIPLEy, 1965). Despite the normalization of the body weight in the AOS-mice, both the seminal vesicles and the nuclei and total volume of the Leydig cells were considerably smaller in these mice than in the lean controls. As a matter of fact these parameters did not display any changes suggestive of an improvement of the endocrine testis function after the overweight of the obese-hyperglycemic mice had been eliminated.

In another series of experiments the effect of overfeeding on the endocrine testis function was studied by comparing testes from normal lean mice with those from mice, in which obesity had been induced by an intraperitoneal injection of $1.5 \mu \mathrm{g} / \mathrm{g}$ body weight of gold thioglucose. The latter compound is known to induce a primary hyperphagia by destroying the hypothalamic centres responsible for the regulation of the food intake (MAYER, 1960; Debons et al., 1962). Fig. 4 shows the values obtained in the mice that were made obese by the induction of hyperphagia, when expressed as percentages of those for the lean controls that were allowed free access to food. It is evident that both the total volume of the Leydig cells and that of the spermatogenic epithelium were within the normal range, despite a considerable increase of the body weight.

Both the quantitative microscopic analyses of testes from obese-hyperglycemic mice in which the overweight had been eliminated and from mice in which hyperphagia and obesity had been induced by injections of gold thioglucose suggest that the depressed gonadotrophin secretion in the obese-hyper-

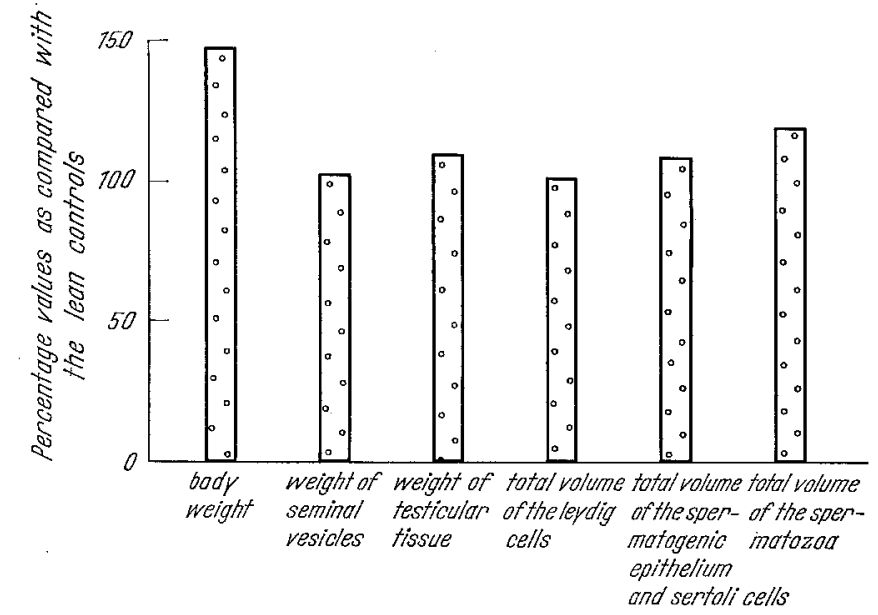

Fig. 4. The body weights (g), the weights of the testicular tissue and seminal vesicles $(\mathrm{mg})$ and the total volumes of different testicular components $\left(\mathrm{mm}^{3}\right)$ in mice with experimentally induced hyperphagia and resulting obesity. The values have been expressed as percentages of the corresponding parameters for lean controls

glycemic mice is due to factors other than overeating and obesity. Among the abnormalities that may be responsible for a depressed gonadotrophin secretion 
in the obese-hyperglycemic syndrome, the impaired glucose metabolism deserves special attention. A progressive atrophy of the sexual organs has, for example, been reported in diabetes following pancreatectomy in rats (Fogrts et al., 1963) and a defective spermatogenesis with a decreased number of Leydig cells has been found in biopsies of the testes from male diabetic patients (SchöFFLING et al., 1963). Our observation that the impairment of the glucose metabolism precedes the appearance of the obesity in the obese-hyperglycemic mice (see above) makes possible studies of the testis function in these animals when they had never been obese and when their body weight was strictly within the normal range.

\section{$\beta$-glucuronidase activity}

Several authors have reported an increased activity of $\beta$-glucuronidase in serum from patients with manifest diabetes (GOLDBARg et al., 1959; Woollen and TURNER, 1965; MELer et al., 1966). Similar observations have been made in serum but not in the liver and renal tissue from alloxan diabetic rats (DoHRMANN and KöHLER, 1966). Since the specific role of $\beta$-glucuronidase in the intermediary metabolism has not been ascertained as yet, the mechanism behind its increased activity in diabetes also remains obscure. It has been postulated that the formation of $\beta$-glucuronidase in diabetes is induced by excessive amounts of mucopolysacharides, which accumulate as a result of the increased formation of uridine diphosphate glucuronic acid through a hyperactive glucuronic acid cycle (Mricer et al., 1966). The latter hypothesis is of particular interest, since it may also explain the considerably increased $\beta$-glucuronidase activity that has been described in advanced arteriosclerosis (MILLER et al., 1966; WEXLER and JUDD, 1966).

Since the obese-hyperglycemic mice are characterized both by an impaired glucose metabolism and signs of vascular complications (HELLMAN, 1965), it was found worth while to study the $\beta$-glucuronidase activity in different tissues from these animals. The enzyme was measured in tissue homogenates and serum at $\mathrm{pH}$ 3.6, using 4-methylumbelliferone- $\beta$-D. glucuronide as substrate. While the free aglycon is highly fluorescent, the low flurorescence of 4-methylumbelliferone in the glycosidic linkage made it possible to use a substrate concentration $(0.1 \mathrm{mM})$ sufficient to saturate the enzyme. The $\beta$-glucuronidase activities found in various tissues from the obese-hyperglycemic mice and their lean litter-mates are shown in Fig. 5. Although the liver and adrenal homogenates displayed considerable activities, only low values were found in the brain and heart. The $\beta$-glucuronidase activity in the serum corresponded to a liberation of $0.73 \pm 0.04$ $\mu \mathrm{g}$ of methylumbelliferone per $100 \mu \mathrm{l}$ serum per hour. There was a significantly higher activity of $\beta$-glucuronidase in the adrenals, whereas no differences were recorded in comparisons with the lean litter-mates, either for the serum or the other tissues included in Fig. 5.

In view of the recent reports of an increased aortic $\beta$-glucuronidase activity in rats with progressively severe aortic arteriosclerosis (WEXLER and JUDD, 1966 ), it is worthy of note that the enzyme activity in the thoracic segment of the aorta was not only one of the lowest among the tissues analysed in the obese mice but also within the same range as was found in the lean siblings. The observation of a considerably higher $\beta$-glucuronidase activity in the adrenals from the obese mice can probably be attributed to the increased adrenocortical activity previously demonstrated in these mice in our laboratory (HedLmar, 1965). The hyperadrenocorticism seems, however, to be a secondary phenomenon in the obese-hyperglycemic syndrome, since it was found that the size and microscopical appearance of the adrenal cortex were closely related to the body weight and were normalized by eliminating overeating (HELLERSTRöM et al., 1962).

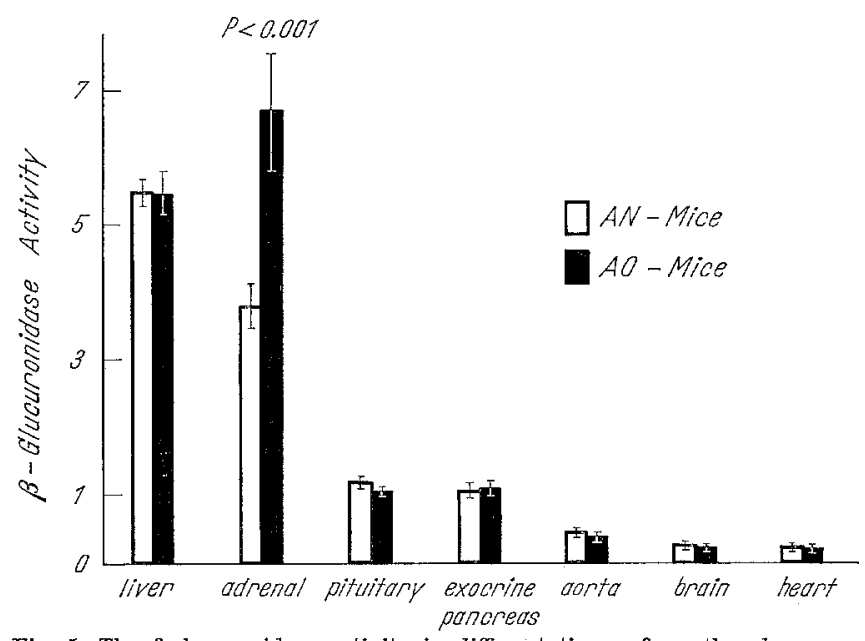

Fig. 5. The $\beta$-glucuronidase activity in different tissues from the obesehyperglycemic mice (AO-mice) and their lean litter-mates (AN-mice). The enzyme activities have been expressed as $\mu \mathrm{g}$ of 4-methylumbelliferone liberated per hour per mg tissue (wet weight) and represent mean values $\div$ S.E.M. When a $t$-test has revealed significant differences between the two types of mice, the corresponding level of significance has been given

\section{Participation of $N A D^{+}$and $N A D P+$ in the dehydrogenation of isocitrate}

The relation between the oxidative, energy-yielding (catabolic) processes and the synthetic, energyconsuming (anabolic) pathways in a tissue is reflected in its enzyme pattern. It has been postulated that the functional separation of catabolic and anabolic pathways can be clearly demonstrated at the isocitrate dehydrogenation step. This step seems to be unique in the mammalian tissues, since one common metabolic step, the oxidative decarboxylation of isocitrate to $\alpha$ ketoglutarate, is made via the $\mathrm{NAD}^{+}$system for the catabolic purpose and via the $\mathrm{NADP}^{+}$system for the anabolic one (KADENBACH et al., 1964). Our interest in isocitrate dehydrogenation in the tissues from the 
obese-hyperglycemic mouse was also stimulated by the assumption that the $\mathrm{NAD}^{+}$-linked enzyme might be rate limiting in the citric acid cycle (CHEN and Praut, 1963; Sanwall et al., 1964; Goebell and KuTngenberg, 1964).

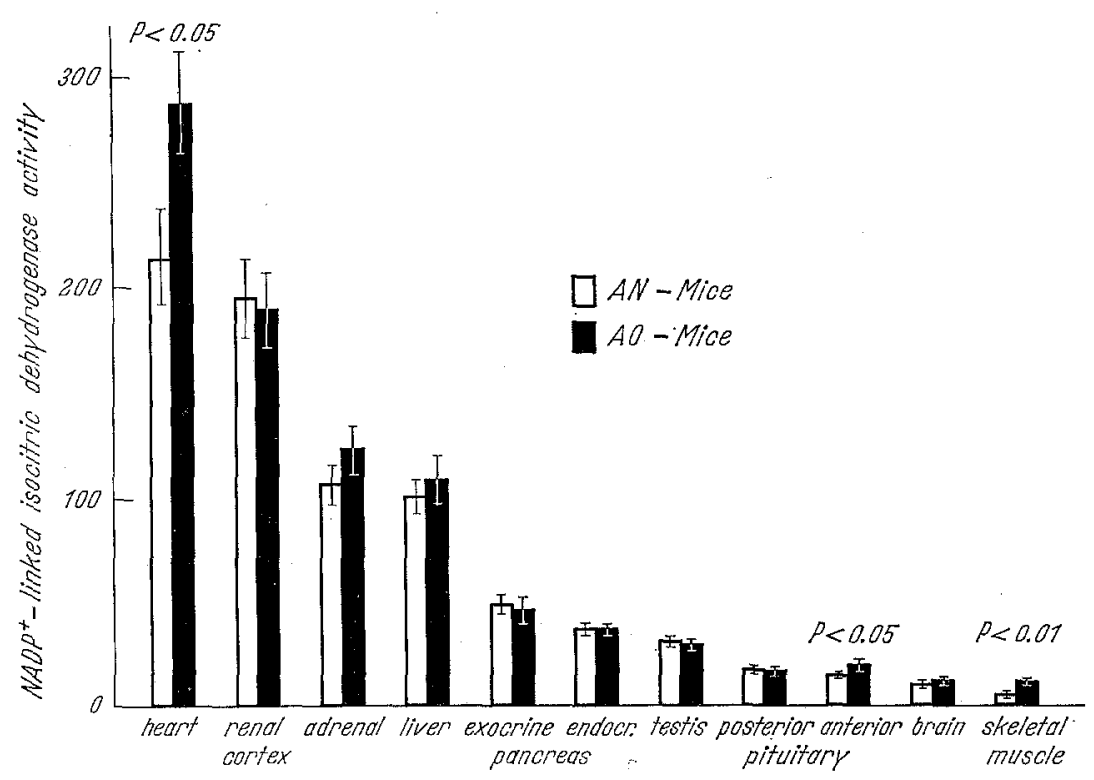

Fig. 6. The NADP+-linked isocitric dehydrogenase activity in different tissues from adult obese-hyperglycemic mice (AO-mice) and their lean sibling controls (AN-mice). The enzyme activity (mean values \pm S.E.M.) has been given per unit of tissue protein and the values expressed as percentages of the liver activity of the AN-mice. When a $t$-test has revealed significant differences between the two types of mice, the corresponding level of significance has been given

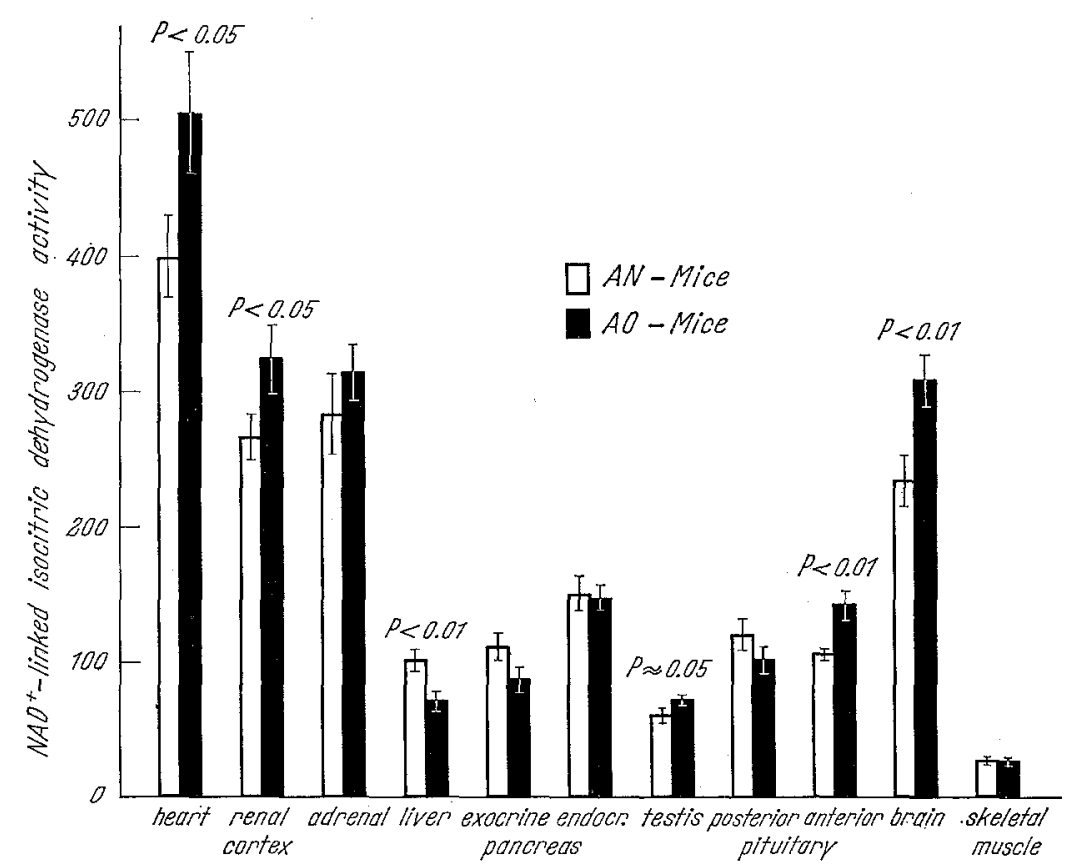

Fig. 7. The NAD + -linked isocitric dehydrogenase activity in different tissues from adult obese-hyperglycemic mice (AO-mice) and their lean sibling controls (AN-mice). The enzyme activity (mean value \pm S.E.M.) has been given per unit of tissue protein and the values expressed as percentages of the liver activity of the AN-mice. When a $t$-test has revealed significant differences between the two types of mice, the corresponding level of significance has been given
In view of the instability of the $\mathrm{NAD}^{+}$-linked isocitric dehydrogenase, the tissues were homogenized in an ice-cold phosphate buffer containing both EDTA and reduced glutathione. Sufficient sensitivity was secured in the following enzyme assays by using fluorimetric measurements of the reduced pyridine nucleotides produced during the incubation. The remaining $\mathrm{NAD}^{+}$and $\mathrm{NADP}^{+}$at the end of the incubation were first destroyed, and. the reduced pyridine nucleotide was then oxidized and transferred into a highly fluorescent product by heating with concentrated sodium hydroxide containing $0.01 \%$ hydrogen peroxide. The details of the procedure for the assay of the two types of isocitric dehydrogenases in very small amounts of tissue will be described elsewhere (HELLMAN, 1966).

The distribution of the two enzymes for isocitrate dehydrogenation in the tissues from obese-hyperglycemic mice and their lean littermates can be seen in Fig. 6 and 7 . The activity of each enzyme has been calculated per unit of tissue protein, the latter being determined by the technique of LowRY et al (1951), and the values obtained expressed as percentages of those for the liver in the lean controls. For the NADP+-linked enzyme the highest activity was noted in the heart and the lowest in the skeletal muscle. In the obese-hyperglycemic mice the NADP+-specific isocitric dehydrogenase activity was slightly increased in the heart and anterior pituitary, while the skeletal muscle displayed values more than twice as high as the lean controls. In the obese-hyperglycemic mice there was a probable increase of the activity of the $\mathrm{NAD}^{+}$-specific isocitric dehydrogenase in the heart, renal cortex and testis and a significant increase in the anterior pituitary and brain. The livers from the obese mice displayed, on the other hand, significantly lower activities of the latter enzymes. Striking differences were noted between the various tissues for the relative contribution of the two oxidized pyridine nucleotides in the enzymatic dehydrogenation of isocitrate. In the lean controls the ratio between the NADP+. and $\mathrm{NAD}^{+}$-linked isocitric dehydro- 
genase activities was found to be about 11 in the liver homogenates but less than 0.5 in the brain (Fig. 8). In the obese-hyperglycemic mice the most pertinent finding was an increase of the liver ratio to

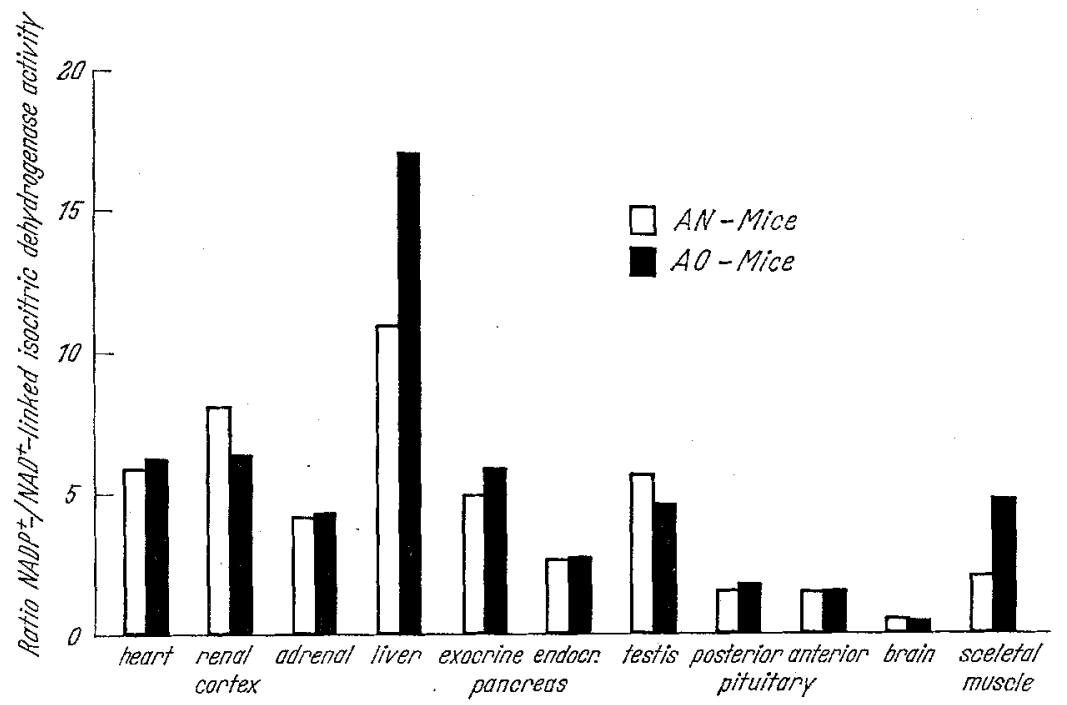

ferent locations, similar ratios (about 3) were encountered for the NADP+- and $\mathrm{NAD}^{+-l i n k e d ~ i s o c i t r i c ~ d e-~}$ hydrogenase activities in both the obese-hyperglycemic mice and their lean litter-mates (HELLMAN, 1966). about 17 and the fact that the corresponding ratio for the skeletal muscle was more than twice as high as that found in the lean litter mates.

No systematic studies have appeared up to now regarding the function and quantitative representation of the different types of cells in the anterior pituitary from the obese-hyperglycemic mice. Since these animals display a probable insufficiency of the pituitary secretion of gonadotrophins, as has been discussed above in the section on the testis function, it seems possible, however, that changes in the cellular composition of the anterior pituitary may provide a simple explanation for the increased activities of both types of isocitric dehydrogenase found in this endocrine organ. Secondarily to the accumulation of fat in the obese-hyperglycemic mice, there will be increased demands on the general circulation, which may be reflected in a higher isocitrate dehydrogenation in the heart tissue. In view of the central position of the liver and muscles for the glucose and fatty acid metabolism, it was of particular interest to note that in the obese-hyperglycemic syndrome both these tissues were characterized by considerably increased ratios for the $\mathrm{NADP}^{+}$-and $\mathrm{NAD}^{+}$-linked isocitric dehydrogenase activities. The superiority of $\mathrm{NADP}^{+}$over NAD+for the reduction of intermediates in fatty acid synthesis is widely accepted. It may therefore be attractive to interpret the observation that the liver dehydrogenation of isocitrate is more dependent on $\mathrm{NADP}^{+}$in the obese-hyperglycemic mice in the light of the hyperlipogenesis which has previously been reported in the obese-hyperglycemic syndrome (ZoMzELY and MAYER, 1959; Shigeta and SHREEve, 1964). When, however, the analyses were extended to adipose tissue at dif-
Fig. 8. The ratios between the activities of the NADP+-linked and $\mathrm{NAD}^{+}$- linked isocitric dehydrogenase activities in different tissues from adult obese-hyperglycemic mice (AO-mice) and their lean sibling controls ( $A \mathrm{~N}$-mice)

\section{References}

CHen, R. F., and G. W. E. PratT: Activation and inhibition of DPN-linked isocitrate dehydrogenase of heart by certain nucleotides. Biochemistry 2, 1023-1032 (1963).

DaNiELsSon, \&., B. HELLMAN and I. B. TäLJEdaT: Unpublished observations. (1966).

Debons, A. F., L. Silver, E. P. Cronkitw, H. A. Johnson, G. Brecher, D. Tenzer and I. L. SchwarTz: Localisation of gold in mouse brain in relation to gold thioglucose obesity. Amer. J. Physiol. 202, 743-750 (1962).

DoHrmanN, R. E., and M. KöHLER : 3 -glucuronidase activity in the serum and in liver and kidney tissue in alloxan diabetes. Abstracts from the Second Annual Meeting of the European Association for the Study of Diabetes. p. 141,1966 .

Dorfman, R. J., and R. A. ShIPLey: Androgens. Biochemistry, Physiology and Clinical Significance. New York, Wiley, 1956.

Foglia, V. G., R. F. Borghelict, R. A. Chimer, E. L. Fernandez-Coltazo, I. SpIndler and O. Wesely: Sexual disturbances in the diabetic rat. Diabetes 12, $231-237(1963)$.

Gepts, W., J. Christophe and J. Mayer: Pancreatic islets in mice with the obese-hyperglycemic syndrome. Lack of effect of carbutamide. Diabetes 9, 63-69(1960).

Gomberi, H., and M. KLINGminberg: DPN-spezifische Isocitrat-Dehydrogenase der Mitochondrien. 1. Kinetische Eigenschaften, Vorkommen und Funktion der DPN-spezifischen Isocitrat-Dehydrogenase. Biochem. Z. 340, 441-464 (1964).

Goldbarg, J. A., E. P. Pineda, B. M. Barks and A. M. RUTENBURG: A method for colorometric determination of $\beta$-glucuronidase in urine, serum and tissue; assay of enzymatic activity in health and disease. Gastroenterology 36, 193-201 (1959).

HAUSBERGER, F. X., and A. J. RAYrSAY : Islet hypertrophy in obesity of mice bearing ACTH-secreting tumours. Endocrinology 65. 165-171 (1959).

HELIERSTRÖM, C.: A method for the microdissection of pancreatic islets in mammals. Acta endocr. (Kbh.) 45, $122-132$ (1964). 
Helierström, C., B. Helliman and S. Larsson: Some aspects of the structure and histochemistry of the adrenals in obese-hyperglycemic mice. Acta path. microbiol. scand. 54, 365-372 (1962).

Heilman, B. : Studies in obese-hyperglycemic mice. Ann. New York Acad. Sci. 131, 541-558 (1965).

HeLlmaN, B.: Unpublished observations (1966).

Hellman, B., C. Hellerström, S. Westman, H. HamMAR and U. Rothinan: Preparation of pancreatic islet cells for biochemical analyses. In: The Structure and Metabolism of the Pancreatic Islets (eds. S. E. Brolin, B. Hellumann and H. Knutson). Oxford, Pergamon Press, p. 193, 1964.

Helliman, B., L. Jacobsson and I. B. TälJEdal: Endocrine activity of the testis in obese-hyperglycemic mice. Acta endocr. (Kbh.) 44, 20—26 (1963).

IngatLs, A. M., M. M. DiokIE and G. D. Sneti : Obese, a new mutation in the mouse. J. Hered. 41, 317-318 (1950).

INGLE, D. J.: Discussion after the paper: The virilizing syndrome in man, submitted by L. J. Soffer, J. L. Gabrilove, J. W. Jailer and M. D. Jacobs. Rec. Progr. Hormone Res. 5, 436 (1950).

KaDPNBACH, B., H. GoEBeLI and M. KuINGENBERG: Differential action of thyroid hormones on enzyme levels of the DPN and TPN specific isocitrate dehydrogenase. Biochem. Biophys. Res. Comm. 14, 335-339 (1964).

Lane, P. W., and M. M. Drokie: Fertile obese male mouse. J. Hered. 45, 56-58 (1954).

LIDELL, C., and B. HELLMAN: The influence of overeating on the endocrine testis function in mice. Metabolism 15, 444-448 (1966).

Lowry, O. H., N. J. Rosebrough, A. L. Farr and R. J. RaNDALL: Protein measurement with the Folin phenol regent. J. biol. Chem. 193, 265-275 (1951).

MAYER, J.: The obese-hyperglycemic syndrome in mice as an example of "metabolic" obesity. Amer. J. clin. Nutr. 8, 712-718 (1960).
Mayer, J., and D. N. Sirtdes: A quantitative method of determination of the diabetogenic activity of growth hormone preparations. Endocrinology 52, 54-56(1953).

Mtrrear, B. F., F. P. Keyms and P. W. Curreri: Betaglucuronidase activity in serum increased by coronary. artery atherosclerosis. Science 152, 775-776 (1966).

Sanwat, B. D., M. W. Zink and C. S. Stachow: Nicotinamide adenine dinucleotide-specific isocitric dehydrogenase. J. biol. Chem. 239, 1597-1603 (1964).

SHIGETA, Y., and W. W. SHREEve : Fatty acid synthesis

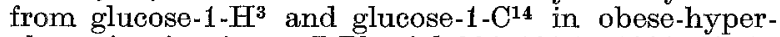
glycemic mice. Amer. J. Physiol. 206, 1085 - 1090 (1964).

Schöffitng, K., K. FederLis, H. DitschunetT and E. F. Pfeifrer: Disorders of sexual function in male diabetics. Diabetes 12, 519-527 (1963).

Smithber., M., and M. N. Runner: Pregnancy induced in geneticailly sterilo mice. J.Hered. 48, 97-100 (1957).

TÄLJEDAL, I. B., and B. HELLMAN : Morphological charact. eristics of the epididymal adipose tissue in different types of hereditary obese mice. Path. Microbiol, 26, $149-157(1963)$.

WESTMAN, S.: Unpublished observations (1966).

WEXLER, B. C., and J. T. JUDD: increased aortic betaglucuronidase activity with progressively severe arteriosclerosis in female breeder rats. Nature (Lond) 209, $383-386$ (1966).

WOOLLEN, J. W., and P. TURNer: Plasma N-acetyl- $\beta$ glucosaminidase and $\beta$-glucuronidase in health and disease. Clin. chim. Acta 12, 671-683 (1965).

ZOMZELY, C., and J. MAYER: Endogenous dilution of administered labeled acetate during lipogenesis and cholesterogenesis in two types of obese mice. Amer. J. Physiol. 196, 956-960 (1959).

Bo HeLtmar, M.D.

Histological Department

University of Umeå.

Umeå 6, Sweden 